\title{
Allelopathic effect of invasive species air potato (Dioscorea bulbifera) on seeds germination of Polyalthia littoralis
}

\author{
ADE AYU OKSARI ${ }^{1, \bullet}$, DEVY SUSANTY ${ }^{2}$, IRVAN FADLI WANDA ${ }^{3}$ \\ ${ }^{1}$ Department of Biology, Universitas Nusa Bangsa. Jl. KH. Sholeh Iskandar Km 4, Bogor 16166, West Java, Indonesia. \\ Tel.: +62-81218011126, +62-85274884343, `email: adeayuoksari@gmail.com \\ ${ }^{2}$ Department of Chemistry, Universitas Nusa Bangsa. J1. KH. Sholeh Iskandar Km 4, Bogor 16166, West Java, Indonesia. \\ ${ }^{3}$ Research Center for Plant Conservation and Botanic Gardens (Bogor Botanic Gardens), Indonesian Institute of Sciences. Jl. Ir. H. Juanda No. 13, Bogor \\ 16122, West Java, Indonesia
}

Manuscript received: 11 October 2018. Revision accepted: 28 February 2019.

\begin{abstract}
Oksari AA, Susanty D, Wanda IF. 2019. Allelopathic effect of invasive species air potato (Dioscorea bulbifera) on seeds germination of Polyalthia littoralis. Nusantara Bioscience 11: 63-70. Dioscorea bulbifera L. (Dioscoreaceae) is included in the Global Weed Compendium and one of the invasive plants that cause environmental problems in many parts of the world. This study aims to determine the effect of allelopathy from various concentrations of leaf and tuber extract from D. bulbifera on seed germination of Polyalthia littoralis (Blume) Boerl. The method used was a Completely Randomized Design (CRD) with seven treatments and three replications. The treatment given was the concentration of $D$. bulbifera extract $10 \%, 20 \%, 40 \%, 60 \%, 80 \%, 100 \%$ and aquadest solvent control. The results of phytochemical screening analysis showed that the extract of leaves and tuber of D. bulbifera did not contain alkaloids, but specifically on leaves extract contained tannins. Both extracts contained steroids, flavonoids, and saponins. Based on the results of the study, total phenolic obtained in the leaf extract as much as $28.81 \pm 2.51 \mathrm{mg}$ TAE/g extract, while the tuber extract had a total phenolic of $6.74 \pm 1.19 \mathrm{mg}$ TAE/g. The results showed that allelopathic substances of $D$. bulbifera affected the germination of $P$. littoralis seeds. Based on DMRT test at $5 \%$ level, it was known that allelopathy concentration of $D$. bulbifera significantly affected the germination rate at concentrations of $20 \%, 60 \%, 80 \%$, and $100 \%$ and significantly affected the coefficient of velocity of germination at a concentration of $20 \%$. But, concentration allelopathy of $D$. bulbifera had no significant effect on the coefficient of uniformity of germination. The concentration that reduced the lowest seed viability was at a concentration of $80 \%$ with an average germination power of $56.67 \pm 7.45 \%$.
\end{abstract}

Keywords: Allelopathy, Dioscorea bulbifera, germination, phytochemicals, Polyalthia littoralis

\section{INTRODUCTION}

Indonesia is currently experiencing a high level of biodiversity loss. Based on IUCN data (2017), there are 1252 threatened plant species in Indonesia. The decline in biodiversity in Indonesia is caused by excessive exploitation of natural resources, land conversion or climate change, and the spread of invasive alien species (IAS), both from within the country (between islands and local) and abroad (Bappenas 2016).

Dioscorea bulbifera L. (Dioscoreaceae) is included in the Global Weed Compendium and one of the invasive plants that cause environmental problems in many parts of the world (Randall 2012). This species also grow rapidly happened in Bogor Botanic Gardens harming many collection plants that host it such as members of Annonaceae (Santosa et al. 2014). D. bulbifera is one of the most dominant invasive weeds in Bogor BotanicGardens because of its rapid propagation and growth as well as their ability to grow in shaded or open conditions (Santosa et al. 2014).

Polyalthia littoralis (Blume) Boerl is a member of Annonaceae (Turner 2012). Based on some preliminary tests, it is known that $P$. littoralis seeds are recalcitrant. Growing this species in the forests for restoration as well as planting them in plantations are often constrained by the recalcitrant nature of the seeds. Recalcitrant seeds have some limitations such as rapid decline in their seed viability in line with the decrease of moisture content and the speed of cell damage due to drying and low temperatures (Walters et al. 2013). This is what causes difficulties in maintaining $P$. littoralis seeds during storage.

The negative impact of invasive plants on the local plants growth is caused by the presence of allelopathic compounds in these invasive plants (Cipollini et al. 2013; Ismaini 2015; Yadav et al. 2016). Previously, Orr et al. (2005) found a potential mechanism that is carried out by invasive plants that can endanger natural species, namely allelopathy. Secondary metabolite compounds such as phenolics, terpenoids, alkaloids, steroids, polyacetylene, and essential oils are reported to have allelopathic activity (Junaidi et al. 2006). Einhellig (1995) stated that phenol compounds that are absorbed into the seeds can inhibit the metabolism of endosperm demolition and can damage the catalytic power of germination enzymes, especially those associated with demolition of carbohydrate.

Several studies have been conducted on allelopathic compounds in invasive plants. D. bulbifera extract can reduce the level of germination in Amaranthus palmeri (Julia 2014). Ismaini (2015) found that allelopathic 
compounds in Clidemia hirta leaves can inhibit seed germination and significantly inhibit the growth of Impatiens platypetala stems and roots. The invasive plant, Abutilon theophrasti has allelopathic compounds which can provide a strong inhibitory effect on the germination of Raphanus sativus and Zea mays (Scepanovic et al. 2007).

Polyalthia littoralis (Blume) Boerl is a plant that widespread in Asian tropical forests (Shu et al. 2011) and D. bulbifera has also spread in the tropics (Magnes et al. 1971). D. bulbifera is an invasive plant contained allelopathic compounds that can inhibit seed germination. The information regarding the effect of $D$. bulbifera allelopathy was inadequate, so the research about the effect of allelopathic compounds on the germination of $P$. littoralis seeds was required.

This study aims to determine the effect of allelopathy from various concentrations of leaf and tuber extract from Dioscorea bulbifera L. on the seed germination of Polyalthia littoralis (Blume) Boerl. and to determine the content of phytochemical compounds in leaves and tubers of D. bulbifera

\section{MATERIALS AND METHODS}

\section{Place and time of research}

This research was conducted at the Chemistry Laboratory, University of Nusa Bangsa, Bogor, Indonesia and the Center for Plant Conservation Botanic GardensLIPI Seed Bank, Bogor, Indonesia. This research was conducted in February-September 2018.

\section{Materials and Instruments}

The ingredients used in this research are Dioscorea bulbifera L. (tubers and leaves), seeds of Polyalthia littoralis (Blume) Boerl, methanol, Mayer reagent, Dragendorf reagent, Wagner reagent, aquadest, diethyl ether, n-hexane, ethanol $80 \%$, ethanol $95 \%, 12 \mathrm{~N} \mathrm{HCl} 12 \mathrm{~N}$, ether, Folin-Ciocalteu reagent, $\mathrm{Na}_{2} \mathrm{CO}_{3}$, limewater, delsene MX-1\%, hot water temperature of $100^{\circ} \mathrm{C}$, insecticides, and sand. D. bulbifera and $P$. littoralis were obtained from Bogor Botanic Gardens collection. P. littoralis (Blume) seeds are seeds that come from fruit that has been ripe and harvested directly from the trees.

The equipment used in this study includes a set of glassware, spray bottles, mortar, oven, hot plate, water bath, RHS Color Chart, spectrophotometer, separator sieve (60 mesh), shaker, evaporating cup, petri dish, and plastic trays.

\section{Procedures}

Extraction of leaf and tuber of D. bulbifera

Leaves and tubers of $D$. bulbifera that were collected in BogorBotanic Gardens-LIPI, were washed thoroughly, chopped, and dried in an oven at $40^{\circ} \mathrm{C}$ until dry (24-48 hours). The dried leaves and tubers were mashed to form a powder and sieved with a 60 mesh sieve. 200 grams of $D$. bulbifera leaf powder was extracted with $2,000 \mathrm{~mL}$ of distilled water for 24 hours. The filtrate was concentrated until a thick extract was obtained.
Phytochemical test of leaf and tuber extract of D. bulbifera

Test of the bioactive content of alkaloids, terpenoids, flavonoids, saponins and tannins (phytochemical test methods) was carried out based on the modification of methods of Harborne (1984).

Alkaloids. As much as $1 \mathrm{~mL}$ of Leaf and tubers extracts were added with $5 \mathrm{~mL}$ of chloroform and $5 \mathrm{~mL}$ of ammonia in a test tube, then divided by three and added 3 drops of $\mathrm{H}_{2} \mathrm{SO}_{4} 2 \mathrm{~N}$ in each tube, allowed to stand for a few minutes until separated. The upper part of each filtrate was taken and tested by Mayer, Wagner, and Deggendorf reagents. Samples contain alkaloids if they produce a white precipitate on Mayer, Red precipitate on Dragendrof reagents and chocolate precipitate on Wagner reagents.

Steroids/terpenoids. As much as $1 \mathrm{~mL}$ of leaf and tubers extract were added to $3 \mathrm{~mL}$ of ethanol and $5 \mathrm{~mL}$ of anhydrous acetic acid, then 10 drops of concentrated sulfuric acid (Liebermann-Burchard) were added. The Changes of color from purple to blue or green indicated the presence of steroids, and the formation of a brownish red color on the surface showed the presence of terpenoids.

Flavonoids. As much as $1 \mathrm{~mL}$ of leaf extracts and tubers were added into $3 \mathrm{~mL}$ of ethanol, heated over the water bath, then $0.1 \mathrm{~g}$ of $\mathrm{Mg}$ and 2 drops of concentrated $\mathrm{HCl}$ were added. The red color in the ethanol layer showed the presence of flavonoids.

Saponins. As much as $1 \mathrm{~mL}$ of Leaf and tubers extracts were put into a test tube, then heated with $10 \mathrm{~mL}$ of distilled water in a water bath. The filtrate was shaken and allowed to stand for 15 minutes. The stable foam formed indicated the presence of saponins.

Tannins. As much as $1 \mathrm{~mL}$ of leaf and tubers extracts were added into $10 \mathrm{~mL}$ of distilled water and then heated in a water bath and 2-3 drops of $\mathrm{FeCl}_{3} 1 \%$ was added. The green, dark blue or greenish black colors formed indicated the presence of tannins.

\section{Total phenolic content}

Measurement of total phenolic content was carried out based on the modification of methods of Andarwulan et al. (1999). Standard solutions of tannic acids were prepared by dissolving $5 \mathrm{mg}$ of tannic acid into distilled water using a $25 \mathrm{~mL}$ measuring flask. Standard solutions are made with concentrations of $0,25,50,75,100,125 \mathrm{mg} / \mathrm{L}$. Testing of total phenolic content was carried out by dissolving $5 \mathrm{~mL}$ of extract with distilled water in a $25 \mathrm{~mL}$ measuring flask and homogenized with a shaker. As much as $1 \mathrm{~mL}$ of the solution was taken and added with $1 \mathrm{~mL}$ of FollinCiocalteu $50 \%$ reagent, allowed to stand for 5 minutes, 1 $\mathrm{mL}$ of $\mathrm{Na} 2 \mathrm{CO} 35 \%$ was added and homogenized in the dark for 1 hour. The absorbance was measured at a wavelength of $725 \mathrm{~nm}$ using a UV-VIS spectrophotometer.

Test the effect of tuber and leaf extracts of D. bulbifera on P. littoralis seed germination

Preparation, characterization, and measurement of seed moisture content. The fruit of $P$. littoralis which was ripe physiologically was extracted and the uniform seeds were selected. The selected seeds were washed with clean water and were dried. Fruit and seed characterization was 
described as descriptively based on direct observation. The Seed characters observed were included the number of wings, color, weight, length, width, the thickness of seeds and internal seed structure using a binocular microscope. The method of measuring the moisture content of the seeds was done using the ISTA Constant Temperature Oven (2015). The seed moisture content (MC) was calculated by the formula:

$$
\mathrm{MC}=\frac{(M 3-M 2)}{(M 2-M 1)} \times 100 \%
$$

Which M1 is the weight of the container used, M2 is the weight of the seed and the container before being ovened, and M3 is the weight of the seed and container after being ovened.

Experiment method. The experimental design used was Completely Randomized Design (CRD) with 7 germination treatments and 3 replications consisting of: without extract of $D$. bulbifera (control), extract of leaf and tubers of $D$. bulbifera with concentrations of 10, 20, 40, 60, 80, and $100 \%$. Each experimental unit used 10 seeds. Before sowing, the seeds were soaked in D. bulbifera extract according to the treatment factors i.e. concentrations of $0,10,20,40,60,80$ and $100 \%$ for 30 minutes.

The germination medium used were sands in plastic trays with $42 \mathrm{~cm} \times 32 \mathrm{~cm}$ x $12 \mathrm{~cm}$ dimension. Each plastic tray contained $30 \mathrm{~kg}$ sands that passed a $1 \mathrm{~mm}$ sieve. The sterilized media was sprinkled with an insecticide around $2.5 \mathrm{~g} / \mathrm{vessel}$ of germination. The seeds are buried just below the surface of the sand with a spacing of $3 \mathrm{~cm} \times 1$ $\mathrm{cm}$. Watering is done every day according to media germination moisture. Observations were carried out every two days with the variables observed were germination capacity, first-day germination, last day germination, germination rate and coefficient of simultaneity of germination. Germination capacity (GC) is calculated by the formula:

$\mathrm{GC}=\frac{\mathrm{n}}{\mathrm{N}} \times 100 \%$ which, $\mathrm{n}=$ seeds that germinate; $\mathrm{N}=$ seeds that are germinated.

The germination rate $(\mathrm{x})$ is calculated by the formula:

$$
x=\frac{\sum n}{\sum(\operatorname{txn})} \times 100
$$

Which, $\mathrm{n}=$ seeds that germinate, $\mathrm{t}=$ day when the seeds germinate.

The coefficient of simultaneity of germination is calculated by the formula:

$$
\frac{\sum n}{\left.\sum\left((T-t)^{2} \times n\right)\right]} \times 100, \text { which } T=\frac{\sum(t \times n)}{\sum n}
$$

Which, $\Sigma \mathrm{n}$ : the total number of seeds germinate; $\mathrm{t} \times \mathrm{n}$ : $\mathrm{n}$ seeds that germinate on day $\mathrm{t}$

\section{Data analysis}

The data obtained were analyzed using descriptive method and analysis with variance test (F test) at 5\% significance level. If the $\mathrm{F}$ test has a significant effect, the means are further tested by Duncan's multiple distance test (Duncan Multiple Range Test/DMRT) at a 5\% real level. The software used is Microsoft Excel and the Statistical Tool for Agricultural Research (STAR 2.0.1).

\section{RESULTS AND DISCUSSION}

\section{Phytochemical screening analysis}

The phytochemical test was carried out to identify secondary metabolites found in leaf extract and tuber of Dioscorea bulbifera L. The results of phytochemical screening analysis (Table 1) showed that the extract of distilled leaves and tubers of $D$. bulbifera did not contain alkaloids. The results of the research of Adeosun et al. (2016) also showed that ethanol extract and distilled water from $D$. bulbifera tuber did not contain alkaloids. However, Adeleye and Ikotun (1989) found that the chloroform extract of Tuber D. bulbifera contained alkaloids namely dihydrodioscorine compounds. Alkaloids are secondary metabolites which are biosynthesized from amino acids (Dewick 2002; Stanforth 2006). Alkaloid which is not detected in the extract can be caused by the non-synthesis of alkaloids in D. bulbifera leaf and tuber samples. In addition, the type of solvent used in extraction can also be a determining factor for the extraction of alkaloids.

Distilled water extracts of leaves and tubers of $D$. bulbifera contain steroids, flavonoids, and saponins (Table 1). Based on the results of color observation, leaf extract was identified as having a higher amount of steroids, flavonoids, and saponins compared to tuber extracts. Leaf extract was identified to contain quite a lot of tannins, while the presence of tannin was not shown in the extract of tuber distilled water. Similar results were shown by studies of $D$. bulbifera tubers originating from India with extraction using ethyl acetate and methanol (Sheikh et al. 2013), where flavonoids, terpenoids, steroids, and saponins were found in ethyl acetate extract, while methanol extract contains flavonoids, terpenoids, cardiac glycosides, and saponins.

Table 1. Phytochemical screening results of extracts of leaves and tubers of Dioscorea bulbifera

\begin{tabular}{lcc}
\hline \multicolumn{1}{c}{ Name of test } & \multicolumn{2}{c}{ Results } \\
\cline { 2 - 3 } & Leaf & Tuber \\
\hline Alkaloids (Mayer) & $(-)$ & $(-)$ \\
Alkaloids (Wagner) & $(-)$ & $(-)$ \\
Alkaloids & $(-)$ & $(-)$ \\
(Draggendrof) & & \\
Steroids/terpenoids & $(++)$ & $(+)$ \\
Flavonoids & $(++)$ & $(+)$ \\
Saponins & $(++)$ & $(+)$ \\
Tannins & $(++)$ & $(-)$ \\
\hline
\end{tabular}

Description: $(+)$ : few, $(++)$ : quite a lot, $(-)$ : None 


\section{Total phenolic}

The total phenolic content of the extract is expressed as equivalent to Tannic Acid Equivalent (TAE). The total phenolic in each extract was tested using standard tannic acid at a wavelength of $725 \mathrm{~nm}$. The regression value obtained from the standard curve was 0.9988 with the linear equation $\mathrm{y}=0.0069 \mathrm{x}-0.0108$ (Figure 1 ).

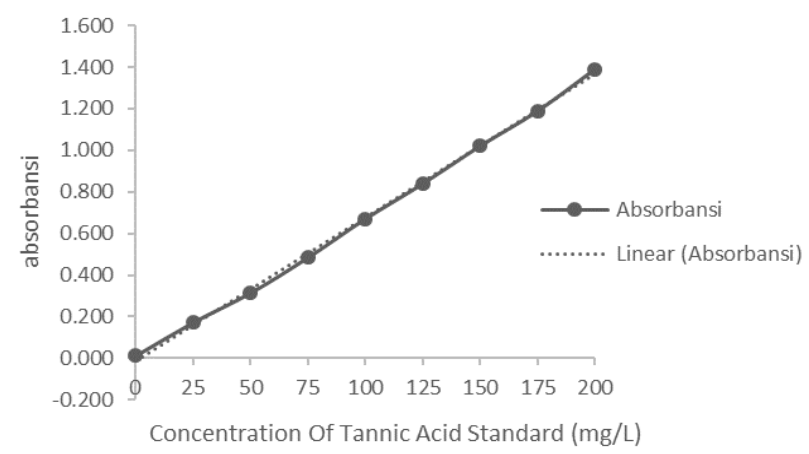

Figure 1. Linear curve standard solution of tannic acid

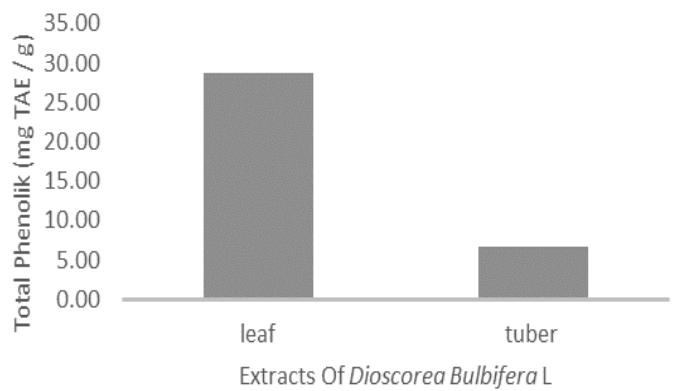

Figure 2. Total phenolic in leaf and tuber extracts of Dioscorea bulbifera
Based on the results of the study, total phenolic in leaf extract was $28.81 \pm 2.51 \mathrm{mg}$ TAE$/ \mathrm{g}$ extract, while the tuber extract had a total phenolic of $6.74 \pm 1.19 \mathrm{mg}$ TAE/g extract. These results showed that the leaf extract had more total phenolic than the tuber extract of $D$. bulbifera (Figure 2).

Phenolic compounds are allelochemical compounds in plants that are generally formed through biosynthetic pathways of shikimate acid (Li et al. 2010). Some phenolic compounds are present extensively in plants, but there are phenolic compounds found only in certain plants or in certain parts of plants (Cheynier 2012) In the context of allelopathy, phenolic compounds include aromatic phenol compounds, benzoic acid, and substituted aldehyde, substituted cinnamic acid, coumarin, tannin, and some flavonoids (Haig 2008).

Inhibition of plant growth by phenolic allelochemical compounds can be through several mechanisms (Li et al. 2010) including (i) phenolic allelochemical compounds can increase the permeability of cell membranes so that the contents of the cell can exit and increase lipid peroxidation; (ii) phenolic allelochemical compounds can inhibit plants in absorbing nutrients from the surrounding environment which have an impact on the normal growth of plants; (iii) phenolic allelochemical compounds can inhibit plant root elongation, cell division, ultra-structural cell changes, and then interfere with the normal growth and development of the whole plant; (iv) phenolic allelochemical compounds has an impact on respiration, namely weakening of oxygen absorption capacity, while its impact on photosynthesis is mainly to reduce chlorophyll levels and photosynthesis rate; (v) phenolic allelochemical compounds enters through plant cell membranes and alters the activity and function of certain enzymes, can reduce or deactivate the physiological activity of plant hormones, which can then inhibit the normal physiological processes of plants; (vi) Some phenolic compounds (ferulic acid and cinnamic acid) can inhibit protein synthesis. The impact of phenolic compounds on the physiological and biochemical changes of plants is shown in (Figure 4).
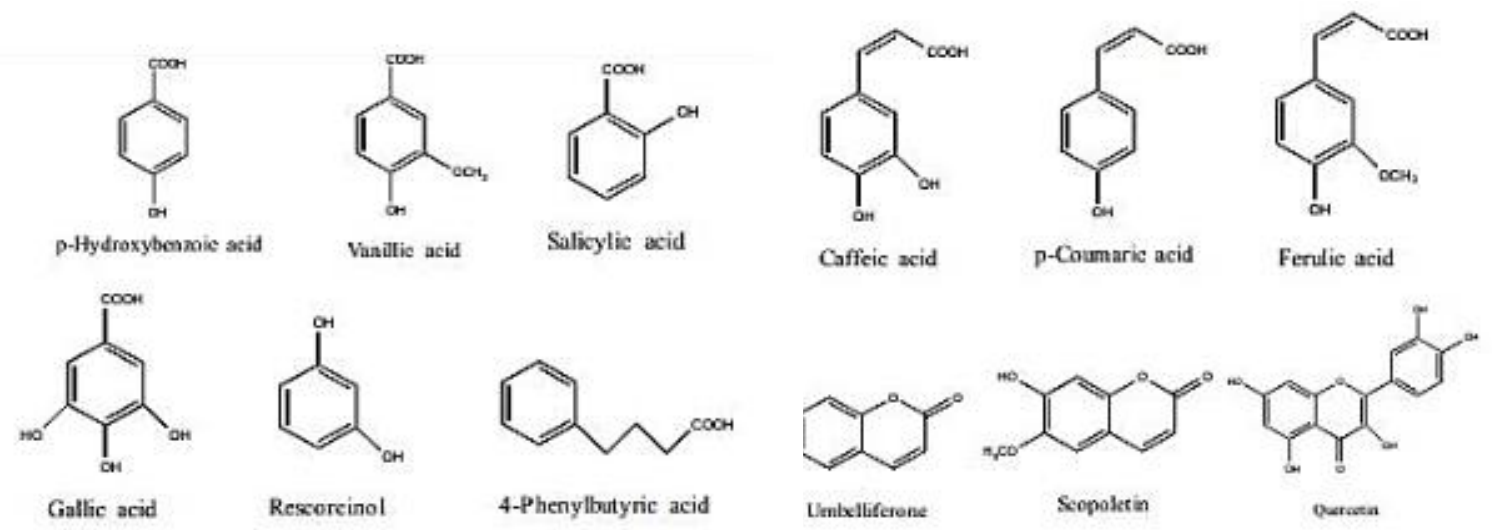

Umixllifarene Scopoletin

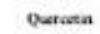

Figure 3. Structure types included in phenolic allelochemicals (Haig 2008) 


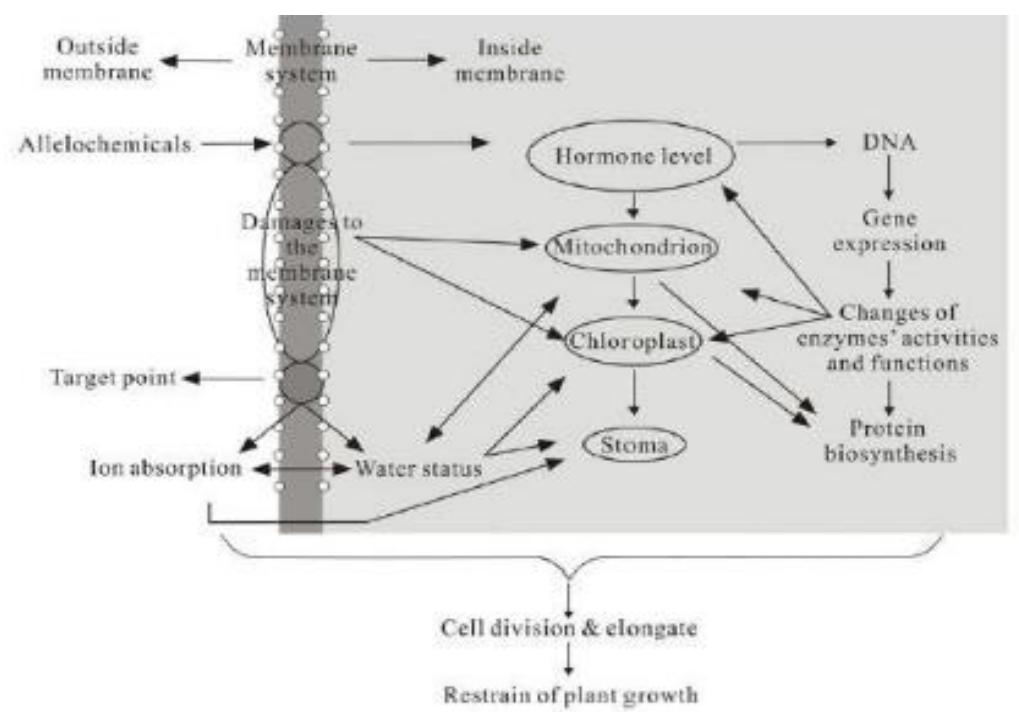

Figure 4. Allelochemical mechanisms (Qiang et al. 2007)

In this study, total phenolic of leaf extract was known more than tuber extract. This phenolic amount affects the allelopathic ability of each extract. Concentrations of phenolic compounds affect seed growth, where generally the higher the concentration of phenolic compounds, germination is increasingly inhibited (Shaukat and Siddiqui 2001; Cipollini et al. 2008). In the study of Shaukat and Siddiqui (2001), several phenolic compounds with varying concentrations (benzoic acid 2.5; 5; and $10 \mu \mathrm{g} / \mathrm{g}$, p-cumaric acid $2.5 ; 5$; and $10 \mu \mathrm{g} / \mathrm{g}$, and caffeic acid $2.5 ; 5 \mu \mathrm{g} / \mathrm{g}$ ) tested on green beans showed the results of more germination was inhibited, but for p-cumaric acid compound, the germination was increased at a concentration of $5 \mu \mathrm{g} / \mathrm{g}$ compared to $2.5 \mu \mathrm{g} / \mathrm{g}$ and it was decreased in concentration of $10 \mu \mathrm{g} / \mathrm{g}$. Types of phenolic compounds also affect germination inhibition. Ishikura, Kojima and Terrazawa (2001) examined several groups of phenolic compounds in seed germination which are known to have several Phenolic compounds that inhibit the lettuce seed germination of Lactuca sativa $L$ and some also accelerate the lettuce seed germination of Lactuca sativa L such as chlorogenic acid, gallic acid and caffeic acid compounds at a concentration of $5 \times 10^{-4} \mathrm{M}$. In addition, Phenolic extract of canola has a significant effect on soybean germination inhibition at a concentration of $0.107 \mathrm{~g} / \mathrm{L}$ (Haddadchi and Gerivani 2009).

\section{Characterization of fruits and seeds of Polyalthia littoralis}

Based on observations of morphological characters, $P$. littoralis Fruit is a single fleshy true fruit (Carnosus) which has an oval-ellipse shape; yellowish green (EHS2015 N134A) when young and reddish orange (EHS2015 44C) in ripe fruit. Each fruit produces 1 elliptical seed with a brownish gray color (EHS2015 166A). The length of the seeds ranged from 8.42 to $11.79 \mathrm{~mm}$ with an average of $9.77 \pm 0.8735 \mathrm{~mm}$, seed diameter ranged from 5.96 to 8.29 $\mathrm{mm}$ with an average of $7.25 \pm 0.5396 \mathrm{~mm}$ while seed weight ranged from 0.1894 to $0.4551 \mathrm{~g}$ with an average of $0.3269 \pm 0.0679 \mathrm{~mm}$. The size of the observed P. Littoralis seeds tends to have the same size $(10-12 \times 6-8 \mathrm{~mm})$, as explained by Shu et al (2011). Morphological characters are influenced by genetics and the environment (Sitompul and Guritno 1995).

The average moisture content of $P$. Littoralis after direct harvesting was $44.3752 \pm 0.1062 \%$. At physiological maturity, the moisture contents of recalcitrant seeds are much higher than orthodox (Chin and Robert 1980). High moisture contents of recalcitrant seeds make them sensitive to desiccation and chilling injury. According to Hong (1998), P. Littoralis seeds are recalcitrant seeds. $P$. Littoralis seeds have several morphological and physiological characteristics as a sign of recalcitrant seeds. Recalcitrant seeds have limitations, namely the rapid decline in seed viability in line with decreasing moisture content and the speed of cell damage due to drying and low temperatures.

\section{Germination of Polyalthia littoralis}

Based on the observation of germination type, $P$. littoralis seeds have an epigeal type (Figure 5). The cotyledons are raised above the surface of the growing medium called epigeal, while the cotyledons remain in the soil with undeveloped hypocotyl called hypogeal. According to Garwood (1995) in the germination process there are 5 combinations of cotyledon character in seedlings, namely fanerocotillar-epigeal-assimilation (FEA), fanerocotillar-epigeal-cotyledon (FEC), fanerocotillar-hypogeal-cotyledon (FHC), cryptocotillarepigeal-cotyledon (KEC) and cryptocotillar-hypogealcotyledon (KHC). Fanerocotillar is a seedling whose cotyledons appear while cryptocotilar cotyledons do not appear. In the $P$. littoralis germination process, a combination of K-E-C was found. The radicle extends to form hypocotyl. $P$ littoralis seeds are polyembryonic, so that the seedlings have $2-4$ roots. In the next development, 
only 1 root can grow continuously. The appearance of the radicle until the opening of the first leaf takes 5-7 weeks (Handayani 2004)

\section{Effect of leaf and tuber extracts of Dioscorea bulbifera on Polyalthia littoralis seed germination}

Based on the results of variance analysis it is known that the concentration of extract significantly affected the germination capacity and coefficient of germination rate, but did not have a significant effect on the coefficient of simultaneity of germination. Allelopathic sources (leaves and tubers) obtained from D. bulbifera do not affect germination capacity, coefficients of germination rate and coefficient of simultaneity of germination. The results of variance analysis also showed that there was no significant interaction between extract concentration and allelopathic sources on germination rate, coefficients of germination rate and coefficient of simultaneity of germination. Germination capacity and coefficients of rate of germination are affected by the accumulation of allelopathic chemical compounds in the soil that reach a concentration threshold (Makoi and Ndakidemi. 2007) The impact of the accumulation of allelopathic compounds is the metabolism of food reserves, disrupting the process of mitosis in the embryo, inhibiting nutrient mobilization as a result of changes in food reserves to embryo, and the presence of water absorption barriers (Einhellig 1995).

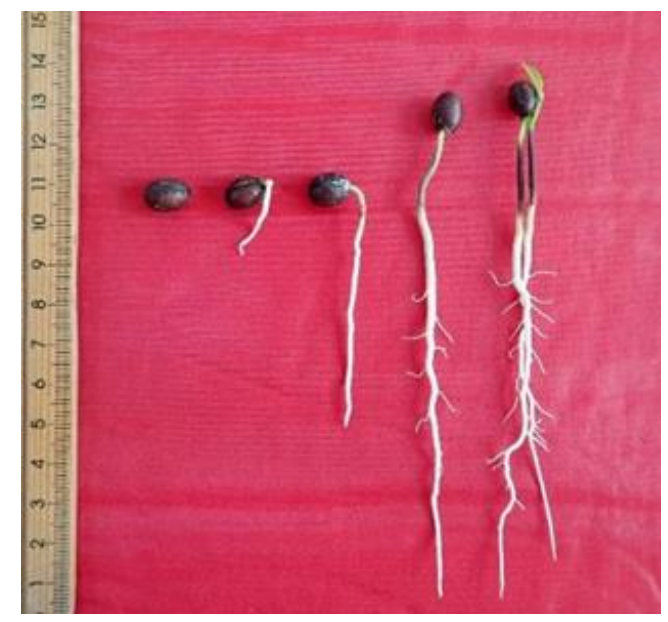

Figure 5. Germination pattern of $P$. littoralis

Table 2. Recapitulation of the effects of concentration, extracts and their interactions on several Polyalthia littoralis germination parameters

\begin{tabular}{lllll}
\hline Parameters & $\begin{array}{l}\text { Factors } \\
\begin{array}{l}\text { Concentra } \\
\text { tion } \\
\text { extract }\end{array}\end{array}$ & $\begin{array}{l}\text { Source } \\
\text { (leaf } \\
\text { tuber) }\end{array}$ & $\begin{array}{r}\text { extract } \\
\text { and }\end{array}$ & $\begin{array}{l}\text { Interac } \\
\text { tion }\end{array}$ \\
\hline $\begin{array}{l}\text { Germination } \\
\text { capacity }\end{array}$ & $*$ & $\mathrm{~ns}$ & $\mathrm{~ns}$ \\
$\begin{array}{l}\text { Coefficient of rate } \\
\text { of germination }\end{array}$ & $*$ & $\mathrm{~ns}$ & $\mathrm{~ns}$ \\
$\begin{array}{l}\text { Coefficient of } \\
\text { simultaneity }\end{array}$ & $\mathrm{ns}$ & $\mathrm{ns}$ & $\mathrm{ns}$ \\
\hline
\end{tabular}

Note: $*=$ significantly different $(\mathrm{F}<0.05) \mathrm{ns}=$ not significantly different $(\mathrm{F}>0.05)$
Concentrations of $20,60,80$ and $100 \%$ of the extract had a significant effect on inhibiting germination (Table 2). The inhibition is thought to occur because phenols, tannins, flavonoids, steroids, and terpenoids affect the $P$. littoralis seed cell membrane. This means that the process of seed germination metabolism is inhibited because the water imbibition process and transport of food reserves are disrupted (Kusuma et al. 2016). According to Santoso and Purwoko (2008), disruption in the imbibition process can inhibit seed germination metabolism. According to Zhao et al. (2010) and Pebriani et al. (2013) stated that allelochemical compounds, especially phenol, causes a decrease of permeability of cell membranes so that the transport of food reserves from the endosperm to the point of growth can be disrupted. In addition, allelochemical compounds also affecting the number of cells does not increase so that it can inhibit the growth of plumula and radicle sprouts through inhibition in the process of cell division and elongation.

The concentration of leaf and tuber extracts of $D$. bulbifera had a significant effect on the coefficient of rate of germination at a concentration of $20 \%$ (Table 3 ). This is suspected, at the concentration of the extract, it can inhibit radicle growth which ecologically grows depends on the internal resources of seeds and also the nutrients that can be absorbed by the seed. Root is one of the most sensitive parts of plants to allelopathy because this is the first part that contact with the allelochemical compounds (Tawaha and Turk 2003; Wakjira et al. 2005). Radicular growth delay has an impact that is relevant to continuity live a seed, composition, and diversity of a community. Structurally, some of the contents of allelopathic compounds are similar to plant hormones (Olofsdotter 1998). In addition, allelochemical mechanisms are also similar to the synthesis of plant hormones (Kruse et al. 2000). Thus, these compounds are thought to affect germination hormones such as gibberellins (Kruse et al. 2000; Rice 1984) or the activity of certain enzymes such as amylase and proteinase needed for seed germination (Rice 1984). Seed germination delay from each species can have important biological implications because this will affect seed formation in natural conditions (Escudero 2000; Chaves et al. 2001) and their opportunities to compete to obtain resources with neighboring species (Xingxinag et al. 2009). The accumulation of allelopathic chemicals in the soil that reaches the concentration threshold can inhibit germination and slowing down time for germination.

The concentration of leaf and tuber extracts of $D$. bulbifera did not give a significant effect on the coefficient of uniformity of germination of $P$. littoralis seeds (Table 3). However, based on the data in Table 3 it can be seen that there is a difference in the simultaneity of the germination value between the control and the treatment given with various extract concentrations of allelopathy. This is also related to the accumulation of allelochemical compounds which can inhibit the normal physiological processes of plants, thus affecting the simultaneity of seeds to germinate. Allelopathic compounds show an important role in influencing the activity of cell elongation and division, photosynthesis, respiration, membrane permeability, 
Table 3. Recapitulation test of the effect of leaf and tuber extracts of D. bulbifera on some germination parameters of $P$. littoralis

\begin{tabular}{lccc}
\hline $\begin{array}{l}\text { Concentration of tuber and } \\
\text { leaf extract }\end{array}$ & $\begin{array}{c}\text { Germination capacity } \\
(\boldsymbol{\%})\end{array}$ & $\begin{array}{c}\text { Coefficient of rate of } \\
\text { germination } \\
\mathbf{F = 4 . 3 8} \mathbf{~ p = 0 . 0 0 3 1}\end{array}$ & $\begin{array}{c}\text { Coefficient of simultaneity of } \\
\text { germination }\end{array}$ \\
\hline 0 & $\mathbf{F = 6 . 0 1} \mathbf{~ p = 0 . 0 0 0 4}$ & $0.0194^{\mathrm{a}} \pm 0.0004$ & $0.0283^{\mathrm{a}} \pm 0.0018$ \\
10 & $93.33^{\mathrm{a}} \pm 7.45$ & $0.0188^{\mathrm{ab}} \pm 0.0004$ & $0.0310^{\mathrm{a}} \pm 0.0018$ \\
20 & $80.00^{\mathrm{ab}} \pm 7.45$ & $0.0175^{\mathrm{b}} \pm 0.0004$ & $0.0335^{\mathrm{a}} \pm 0.0018$ \\
40 & $63.33^{\mathrm{b}} \pm 7.45$ & $0.0183^{\mathrm{ab}} \pm 0.0004$ & $0.0334^{\mathrm{a}} \pm 0.0018$ \\
60 & $73.33^{\mathrm{ab}} \pm 7.45$ & $0.0182^{\mathrm{ab}} \pm 0.0004$ & $0.0329^{\mathrm{a}} \pm 0.0018$ \\
80 & $65.00^{\mathrm{b}} \pm 7.45$ & $0.0192^{\mathrm{a}} \pm 0.0004$ & $0.0291^{\mathrm{a}} \pm 0.0018$ \\
100 & $56.67^{\mathrm{b}} \pm 7.45$ & $0.0188^{\mathrm{ab}} \pm 0.0004$ & $0.0313^{\mathrm{a}} \pm 0.0018$ \\
\hline
\end{tabular}

Note: Numbers followed by the same letterr are not significantly different at $p<0.05$ using DMRT

stomatal opening, mineral ion absorption, and protein and nucleic acid metabolism (Baziramakenga et al. 1997; Qasem and Foy 2001). Stress caused by environmental factors such as humidity, nutrients, temperature, planting density, light, also pathogens affects the production, persistence, and effectiveness of allelopathy (Weidenhamer 1996). Generally stresses both biotic and abiotic tend to increase the production of secondary metabolites.

In this study, it was found that the extract of distilled leaves and tubers of Dioscorea bulbifera L. contained steroids, flavonoids, saponins, and tannins. The total phenolic in leaf extract was $28.81 \pm 2.51 \mathrm{mg}$ TAE $/ \mathrm{g}$ extract, while the tuber extract had a total phenolic of 6.74 $\pm 1.19 \mathrm{mg}$ TAE$/ \mathrm{g}$ extract. Allelopathy obtained from the extract at concentrations of $20,60,80$ and $100 \%$, has a significant effect on inhibiting germination capacity. Leaf and tubers extracts of $D$. bulbifera had a significant effect on the coefficient of rate of germination at a concentration of $20 \%$. The concentration of tuber and leaf extracts of $D$. bulbifera did not give a significant effect on the coefficient of germination simultaneity of $P$. littoralis seeds.

\section{ACKNOWLEDGEMENTS}

This research was funded by the Ministry of Research, Technology and Higher Education of the Republic of Indonesia. We would like to thank to Director of Center for Plant Conservation Botanic Gardens-LIPI and Rector of Nusa Bangsa University for supporting this research. Many thanks to Dr. Didit Okta Pribadi and Dr. Dian Latifah for giving permission at the Seed Bank of Bogor Botanic Gardens. We are also grateful for the generous assistance from all team members of LIPI Botanic Gardens Seed Bank: Harto, Aulia Hasan Widjaya, Mimin, Fahmi, Deden and all team members of Biology and Chemistry Laboratory: Asep, April.

\section{REFERENCES}

Adeleye A, Ikotun T. 1989. Antifungal activity of dihydrodioscorine extracted from a wild variety of Dioscorea bulbifera L. J Basic Microbiol 29: 265-267.

Adeosun OM, Arotupin DJ, Toba OA, Adebayo AA. 2016. Antibacterial activities and phytochemical properties of extracts of Dioscorea bulbifera Linn (air potato) tubers and peels against some pathogenic bacteria. J Phytopharmacol 5: 20-26.

Andarwulan N, Fardiaz D, Wattimena GA, Shetty K. 1999. Antioxidant activity associated with lipid and phenolic mobilization during seed germination of Pangium edule Reinw. J Agric Food Chem 47: 31583163 .

Bappenas. 2016. Indonesia Biodiversity Strategy and Action Plan 20152020. Bappenas, Jakarta. [Indonesian]

Baziramakenga R, Leroux GD, Simard RR, Nadeau P. 1997. Allelopathic effects of phenolic acids on nucleic acid and protein levels in soybean seedlings. Can J Bot 75: 445-450.

Chaves N, Sosa T, Escudero JC. 2001. Plant growth inhibiting flavonoids in exudate of Cistus ladanifer and in associated soils. J Chem Ecol 27: 623-631.

Cheynier V. 2012. Phenolic compounds: From plants to foods. Phytochem Rev 11: 153-177.

Chin HF, Roberts EH. 1980. Recalcitrant crop seeds. Tropical Press SND, DHDI, Kuala Lumpur.

Cipollini A, Kendra, Flint N, Wesley. 2013. Comparing allelopathic effects of root and leaf extracts of invasive Alliaria petiolata, Lonicera maackii and Ranunculus ficaria on germination of three native woodland plants. Ohio J Sci 112: 37-43.

Cipollini D, Enright S, Stevenson R, Eyles A. 2008. Phenolic metabolites in leaves of the invasive shrub, Lonicera maackii, and their potential phytotoxic and anti-herbivore effects, J Chem Ecol 34: 144-152.

Dewick PM. 2002. Medicinal Natural Products: A Biosynthetic Approach, John Wiley and Sons, United Kingdom.

Einhellig FA. 1995. Allelopathy: Current status and future goals. In: Inderjit, Dakhsini KMM, Einhellig FA (eds.). Allelopathy, Organism, Processes and Applications. American Chemical Society, Washington $\mathrm{DC}$

Escudero A, Albert MJ, Pita JM, Pérez-Garcia F. 2000. Inhibitory effects of Artemisia herba-alba on the germination of the gypsophyta Helianthemum squamatum. Plant Ecol 148: 71-80.

Garwood NC. 1995. Studies in Annonaceae. XX. Morphology and ecology of seedlings, fruits and seeds of selected Panamian species. Botanische Jahrbucher Systematische, Band 117, Helf (1/2), Stuttgart.

Haddadchi GR, Gerivani Z. 2009. Effects of Phenolic extracts of canola (Brassica napus L.) on germination and physiological responses of soybean (Glycine max L.) seedlings. Intl J Plant Product 3: 63-74.

Haig T. 2008. Allelochemicals in Plants. In: Zeng R, Sen, Maliik AU, Luo SM (eds) Allelopathy in Sustainable Agriculture and Forestry. Springer, Nederland.

Handayani T. 2004. Perkecambahan benih sepuluh jenis anggota Suku Annonaceae. Biosmart 6: 109-112. [Indonesian]

Harborne JB. 1984. Phytochemical Method. Chapman and Hall ltd., London

Hong TD, Linington S, Ellis RH. 1998. Compendium of Information on Seed Storage Behaviour. The Trustees, Royal Botanic Gardens, Kew, UK.

Ishikura Y, Kojima Y, Terrazawa M. 2001. Effects of phenolic compounds on seed germination of shirakamba birch, Betula platyphylla var. japonica. Eurasian J For Res 2: 17-25.

Ismaini L. 2015. Pengaruh alelopati tumbuhan invasif (Clidemia hirta) terhadap germinasi biji tumbuhan asli (Impatiens platypetala). Pros Sem Nas Masy Biodiv Indon 1: 834-837. [Indonesian] 
ISTA. 2015. International Rules for Seed Testing. International Seed Testing Association (ISTA). Bassersdorf, Switzerland.

IUCN. 2017. Red List Category Summary Country Totals (Plants). www.iucnredlist.org.

Julia. 2014. Weed Warfare: Investigating Allelopathy: Year IV. www.amnh.org.

Junaedi A, Chozin MA, Kim KH. 2006. Ulasan perkembangan terkini kajian alelopati. Hayati 13: 79-84. [Indonesian]

Kruse M, Strandberg M, Strandberg B. 2000. Ecological Effects of Allelopathic Plants: A Review. NERI Technical Report No. 315. National Environmental Research Institute, Silkeborg, Denmark.

Kusuma AVC, Chozin MA, Guntoro D. 2016. Senyawa fenol dari tajuk dan umbi teki (Cyperus rotundus L.) pada berbagai umur pertumbuhan serta pengaruhnya terhadap perkecambahan gulma berdaun lebar. J Agron Indonesia 45: 100-107. [Indonesian]

Li ZH1, Wang Q, Ruan X, Pan CD, Jiang DA. 2010. Phenolics and plant allelopathy. Molecules 15: 8933-8952.

Magness JR, Markle GM, Compton CC. 1971. Food and Feed Crops of the United States. Interregional Research Project IR-4, 1971. Univ of Purdue, USA.

Makoi JHJR, Ndakidemi PA. 2007. Biological, ecological and agronomic significance of plant phenolic compounds in rhizosphere of the symbiotic legumes. African J Biotechnol 6: 1358-1368.

Olofsdotter M. 1998. Allelopathy for weed control in organic farming. In: El-Bassam N, Behl RK, Prochnow B (Eds.) Sustainable Agriculture for food, energy and industry-strategies towards achievement. James and James Science Publisher, London.

Orr SP, Rudgers JA, Clay K. 2005. Invasive plants can inhibit native tree seedlings: testing potential allelopathic mechanisms. Plant Ecol 181: 153-165.

Pebriani R, Linda, Mukarlina. 2013. Potensi ekstrak daun sembung ramba (Mikania micrantha H.B.K) sebagai bioherbisida terhadap gulma maman ungu (Cleome rutidosperma D.C) dan rumput bahiam (Paspalum notatum Flugge). Protobiont 2: 32-38. [Indonesian]

Qasem JR, Foy CL. 2001. Weed allelopathy, its ecological impacts and future prospects: a review. J Crop Prod. 4: 43-119.

Qiang W, Xiao R, Zhaohui, L. 2007. Autotoxicity of plants and research of coniferous forest autotoxicity. Scientia Silvae Sinicae 43: 134-142.

Randall RP. 2012. A Global Compendium of Weeds. Department of Agriculture and Food, Western Australia.

Rice EL, 1984. Allelopathy. 2 Edition. Academic Press, Orlando, FL.

Santosa E, Widiyanto G, Lontoh AP, Agustin EK, Takahata K, Mine Y, Sugiyama N. 2014. Invasive weeds in Bogor Botanic Gardens,
Indonesia and its implication on surrounding landscapes. Buletin Kebun Raya 17: 113-126.

Santoso BB, Purwoko BS. 2008. Pertumbuhan bibit tanaman jarak pagar (Jatropa curcas L.) pada berbagai kedalaman dan posisi tanam benih. Bul Agron 36: 70-77. [Indonesian]

Scepanovic M, Novak N, Baric K, Ostojic Z, Galzina N, Gorsic M. 2007. Allelopathic effect of two weed species, Abutilon theophrasti Med. and Datura stramonium L. On germination and early growth of corn. Agronomski Glasnik 6: 459-472.

Shaukat SS, Siddiqui A. 2001. Effect of some phenolic compounds on survival, infectivity and population density of Meloidogyne javanlca in Mungbean. Nematol Medit 29: 123-126.

Sheikh N, Kumar Y, Misra AK, Pfoze L. 2013. Phytochemical screening to validate the ethnobotanical importance of root tubers of Dioscorea species. J Med Plant Stud 1: 62-69.

Shu TC, Bingtao L, Gilbert MG. 2011. Annonaceae. Fl China 19: 672713.

Sitompul SM, Guritno B. 1995. Analisis Pertumbuhan Tanaman. UGM Press, Yogyakarta. [Indonesian]

Stanforth SP. 2006. Natural product chemistry at a glance. Blackwell Publishing, UK

Tawaha AM, Turk MA. 2003. Allelopathic effects of black mustard (Brassica nigra) on germination and growth of wild barley (Hordeum spontaneum). J Agron Crop Sci189: 298-303.

Turner IM. 2012. Annonaceae of Borneo: a review of the climbing species. Gard Bull Singapore 64: 371-479.

Wakjira M, Berecha G, Bulti B. 2005. Allelopathic effects of Parthenium hysterophorus extracts on seed germination and seedling growth of lettuce. Trop Sci 45: 159-162.

Walters C, Berjak P, Pammenter N, Kennedy K, Raven P. 2013. Preservation of recalcitrant seeds. Science 339: 915-916.

Weidenhamer JD. 1996. Distinguishing resource competition and chemical interference-overcoming the methodological impasse. Agron J 88: 866-875.

Xingxinag G, Li, M Zongjung G, Changsong L, Zuowen S. 2009 Allelopathic effects of Hemisterpa lyrata on the germination and growth of wheat, sorghum, cucumber, rape and radish seeds. Weed Biol Manag 9: 243-249.

Yadav v, Singh NB, Singh H, Singh A, Hussain I. 2016. Allelopathic invasion of alien plant species in India and their management strategies: A review. Trop Plant Res 3: 87-101.

Zhao HL, Qiang W, Xiao R, Cun DP, De AJ. 2010. Phenolics and plant allelopathy. Molecules 15:8933-8952. 